\title{
(6) OPEN ACCESS \\ Cutaneous manifestations of tuberous sclerosis complex and the paediatrician's role
}

\author{
Michael A Cardis, Cynthia Marie Carver DeKlotz
}

MedStar Washington Hospital Center/MedStar Georgetown University Hospital, Washington, DC, USA

\section{Correspondence to} Dr Cynthia Marie Carver DeKlotz, 5530 Wisconsin Avenue, Suite 730, Chevy Chase, MD 20815, USA: Cynthia.M.DeKlotz@medstar.net

Received 12 September 2016 Revised 23 February 2017 Accepted 24 February 2017 Published Online First 27 March 2017

\section{ABSTRACT}

Tuberous sclerosis complex (TSC) is a multisystem genetic disorder stemming from unregulated activation of the mammalian target of rapamycin (mTOR) pathway, resulting in the growth of hamartomas in multiple organs. TSC-related skin lesions often develop early in life and can be disfiguring, emotionally distressful and even painful at times. Recognition of TSC-associated skin features by paediatricians can be a catalyst for facilitating early implementation of treatment strategies and establishing appropriate follow-up care. The range of potential treatment options for symptomatic or disfiguring TSC-associated skin lesions includes nonpharmacological (surgical excision, laser therapy) and pharmacological (eg, topical or systemic mTOR inhibitors) alternatives. In this review, we discuss the relevance of TSC-associated skin findings, highlight available treatment options, review guideline recommendations and emphasise the role of the primary care physician in the management of this complex disease.

\section{INTRODUCTION}

Tuberous sclerosis complex (TSC) is a multisystem disorder that affects an estimated 40000 individuals in the USA and approximately 2 million people worldwide, with a birth incidence of about 1 in $6000 .{ }^{1-3}$ Mutations in the tumour-suppressor gene TSC1 (encoding hamartin) or, more commonly, TSC2 (encoding tuberin) are implicated in the pathogenesis of TSC via a loss of inhibition of the mammalian target of rapamycin (mTOR) pathway, allowing subsequent growth of hamartomas in various organs, including the brain (cortical tubers, subependymal nodules, subependymal giant cell astrocytomas (SEGAs)), kidneys (renal angiomyolipomas), lung (lymphangioleiomyomatosis (LAM)), heart (cardiac rhabdomyomas) and skin. ${ }^{45}$

Cutaneous findings are the most common and readily visible manifestation of TSC. More than $90 \%$ of patients with TSC have one or more skin lesions, which usually develop early in life. ${ }^{5}$ It is important for the paediatrician to be able to identify TSC-associated skin manifestations to ensure prompt diagnosis, early treatment initiation and appropriate referral for follow-up of other TSC-related sequelae. This review focuses primarily on cutaneous TSC-associated features, available treatment options and guideline recommendations regarding the management of patients with TSC.

\section{DIAGNOSIS OF TSC}

Outside of positive genetic testing confirming a pathological TSC1 or TSC2 mutation, the clinical diagnosis of TSC relies on a combination of identifiable major and minor characteristics, with cutaneous findings composing a large part of both major (hypomelanotic macules, angiofibromas, ungual fibromas, shagreen patch) and minor ('confetti' skin lesions) features (table 1). ${ }^{6}$ To establish a 'definite' clinical diagnosis of TSC, one must document either two major features or one major feature with two or more minor features. One can garner a 'possible' clinical diagnosis with the identification of either one major or two or more isolated minor features. ${ }^{6}$

Cutaneous manifestations of TSC are readily apparent upon thorough physical examination. In addition to internal organ evaluation, a detailed dermatological examination is recommended upon

Table 1 Tuberous sclerosis complex diagnostic criteria: major and minor features ${ }^{6}$

Major features*

1. Hypomelanotic macules ( $\geq 3$, at least $5 \mathrm{~mm}$ diameter)

2. Angiofibromas $(\geq 3)$ or fibrous cephalic plaque

3. Ungual fibromas $(\geq 2)$

4. Shagreen patch

5. Multiple retinal hamartomas

6. Cortical dysplasiast

7. Subependymal nodules

8. Subependymal giant cell astrocytoma

9. Cardiac rhabdomyoma

10. Lymphangioleiomyomatosisł

11. Angiomyolipomas $(\geq 2) \ddagger$

¥Combination of lymphangioleiomyomatosis and angiomyolipomas without other features does not meet criteria for diagnosis. 

of tuberous sclerosis complex-associated cutaneous manifestations. $^{8}$ This figure was published in Dermatology, 3rd ed, Chapter 61: Neurofibromatosis \& Elsevier 2012.
Figure 1 Age-dependent expression Bolognia JL, Jorizzo JL, Schaffer JV, Tuberous Sclerosis, 925-942, copyright

DEVELOPMENT OF CUTANEOUS FEATURES IN TUBEROUS SCLEROSIS

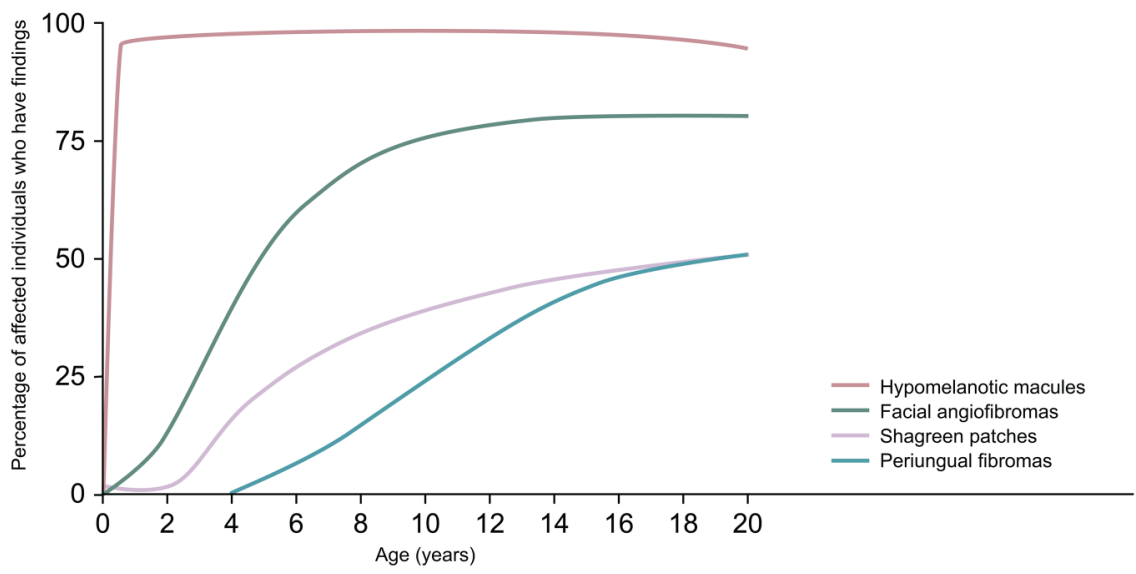

diagnosis of TSC, followed by at least annual skin examinations. ${ }^{7}$ Patients should be advised to use sun protection as a preventive measure to minimise the appearance of some skin lesions.

\section{CLINICAL PRESENTATION OF TSC-ASSOCIATED CUTANEOUS MANIFESTATIONS}

The subtypes of skin lesions tend to develop in an agedependent manner, many arising early in life. ${ }^{8}$ Figure 1 provides a general timeline when certain lesions are more likely to be seen, allowing physicians examining paediatric patients to tailor their index of suspicion accordingly. Some cutaneous features can be subtle, especially in young children, and they are not all specific for TSC.

Facial angiofibromas, sometimes erroneously referred to as adenoma sebaceum, are the most visually apparent TSC-associated, often starting to appear within the first $2-5$ years of life and ultimately occurring in approximately $75 \%$ of patients. ${ }^{9} 10$ They are usually pink to red-brown papulonodules with a smooth, glistening surface and are typically distributed symmetrically on the face, at times mistaken for acne (figure 2A). ${ }^{9}{ }^{10}$ Angiofibromas start small and gradually increase in size, with their growth being augmented by puberty. ${ }^{10}$ Fibrous cephalic plaques are histologically similar and represent a larger variant of angiofibromas. ${ }^{9} 10$ They are raised, firm plaques, usually located on the forehead or scalp and have a tan to yellow-brown colour. ${ }^{9}$ Fibrous cephalic plaques, which can occur at any age, vary in size and shape and can grow to as large as several centimetres in diameter. ${ }^{9}$

Hypomelanotic macules are often the earliest and most frequently reported cutaneous finding in TSC. ${ }^{9} 10$ They present as hypopigmented macules and patches of various morphologies and should not be confused with de-pigmented patches seen in other pigmentary disorders such as vitiligo. In fair-skinned individuals, hypomelanotic macules can be difficult to identify, necessitating the use of a Wood lamp to make them more conspicuous. ${ }^{911}$ Medium to large (1-12 cm in diameter) hypopigmented patches are one of the earliest visible signs of TSC, occurring in $>50 \%$ of children at birth and in nearly all patients by the age of $2 .^{9} 10$ These patches are referred to as 'ash leaf' spots because they can resemble the leaf of the eastern mountain ash tree, shaped like a long oval with one rounded and one tapered end. ${ }^{9} 10$ Polygonal 'thumbprint'-like macules are the most commonly observed morphology and are usually smaller $\left(0.5-2 \mathrm{~cm}\right.$ in diameter) than the ash-leaf type. ${ }^{9}$ Hypomelanotic macules appear asymmetrically and are most common on the
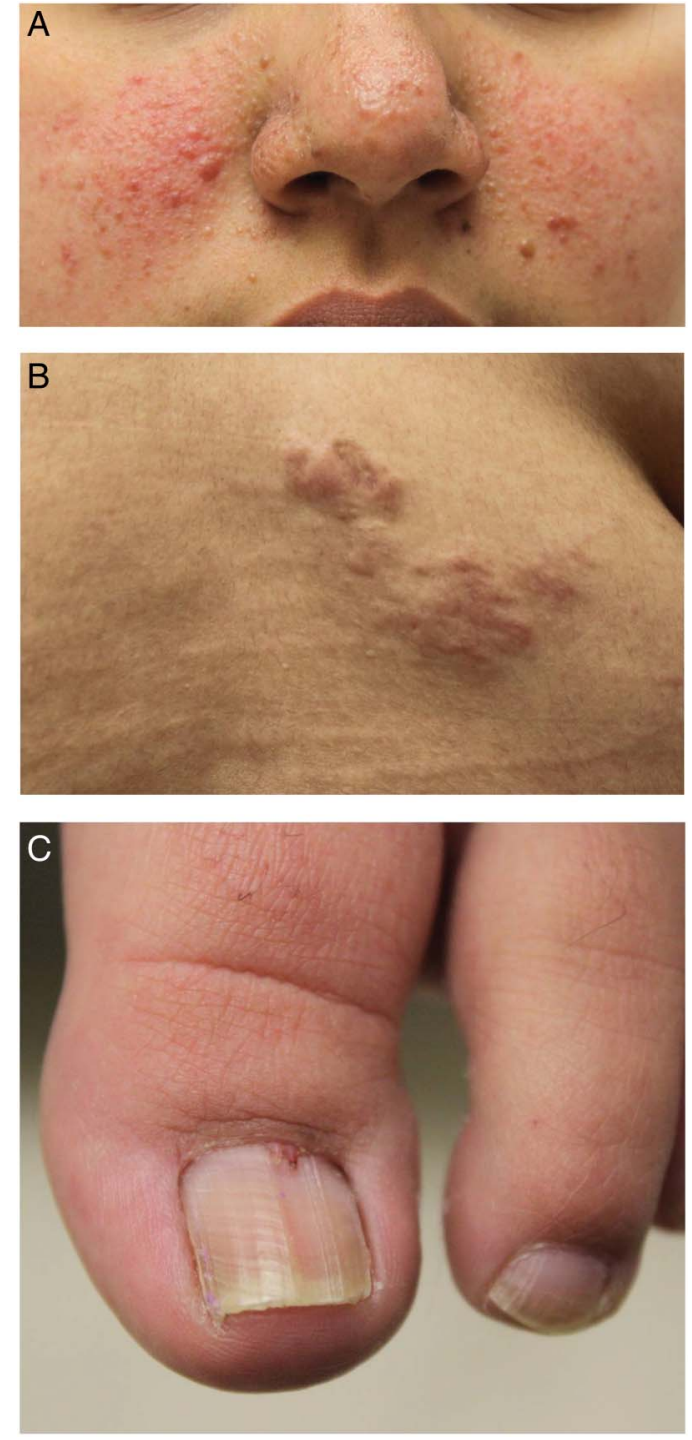

Figure 2 Representative skin lesion subtypes in tuberous sclerosis. (A) Facial angiofibromas, (B) shagreen patch and (C) periungual or subungual fibromas (also known as Koenen tumours).

trunk and buttocks. Scalp involvement is rare, but when present can lead to poliosis. 910

'Confetti-like' skin lesions, another type of hypomelanotic macule, have been reported to occur in $2.8-28 \%$ of patients 
with TSC.9 1012 These appear as numerous, small (approximately 1-3 $\mathrm{mm}$ in diameter) hypopigmented macules that occur symmetrically; they are typically spread over the distal extremities. $^{9} 10$ Confetti-like skin lesions can appear any time from childhood to adulthood. ${ }^{6} 910$

Shagreen patches, a type of connective tissue hamartoma, are found in approximately half the patients with TSC. They typically develop during the first decade of life ${ }^{9} 10$ and are elevated pink to yellow-brown plaques with an orange peel-like texture, ranging from several millimetres to several centimetres in length (figure 2B). ${ }^{9} 10$ Shagreen patches are asymmetric and usually appear on dorsal surfaces, such as the back and the lumbosacral regions, but occasionally occur on the chest or the abdomen. ${ }^{9} 10$

Finally, periungual or subungual fibromas, also called Koenen tumours, are seen in approximately $15 \%$ of patients with TSC and are often observed in early adolescence. ${ }^{9} 10$ These nodules are often red to skin-coloured and typically appear near the proximal nail fold of the toenails (figure 2C) or, less commonly, the fingernails. One of the initial features of ungual fibroma is a nail groove without tumours. ${ }^{9} 10$

\section{TREATMENT OF TSC-ASSOCIATED CUTANEOUS DISORDERS}

International TSC management guidelines recommend that any rapidly changing, disfiguring or symptomatic TSC-associated skin lesion be treated according to clinical context and type of lesion, using methods such as surgery, lasers or topical mTOR inhibitors. $^{7}$ Determining the best approach to the treatment of cutaneous lesions also depends on clinical presentation, severity and presence of other TSC manifestations (table 2). ${ }^{7}{ }^{13}$ In patients with growing SEGA, angiomyolipoma or LAM, treatment with systemic mTOR inhibitors, which address the underlying pathophysiology of the disease, might be indicated and is also likely to result in simultaneous improvement of skin lesions. ${ }^{13-16}$ However, systemic mTOR inhibitors can contribute to surgical complications and delayed wound healing; ${ }^{17-19}$ therefore, elective procedures (eg, cutaneous surgery, laser treatment) might best be avoided while on systemic therapy. In patients not receiving systemic treatment, topical mTOR inhibitors or surgical procedures may be indicated.

\section{Systemic treatment with mTOR inhibitors}

Rapamycin (sirolimus) and its analogues (eg, everolimus) inhibit the mTOR complex and, ${ }^{20}$ as a result, impede mTOR overactivation, which may shrink existing lesions and prevent tumour growth associated with TSC. Oral mTOR inhibitors have proved effective in the treatment of a range of TSC-related manifestations. $^{14-16}$ Systemic mTOR inhibitor-associated adverse effects should be monitored, and commonly reported events include stomatitis, upper respiratory tract infection, wound healing complications and hypercholesterolaemia. ${ }^{21} 22$ If side effects become severe or intolerable, dose adjustments or interruptions may be necessary. 2122

Oral sirolimus is currently approved by the US Food and Drug Administration (FDA) and the European Medicines Agency (EMA) for the treatment of pulmonary LAM associated with TSC $^{22}$ and is being studied for the treatment of cutaneous TSC-related manifestations. ${ }^{23-28}$ A recent retrospective study showed positive long-term effects of oral sirolimus on various skin lesions in 14 women being treated for TSC LAM. ${ }^{14}$ Of 11 patients with baseline photographs of their skin lesions, significant improvements were observed in angiofibromas and shagreen patches $(\mathrm{p}=0.018$ and 0.039 , respectively), but not in ungual fibromas $(p=0.109)$, after median treatment durations of 12,10 and 6.5 months, respectively. ${ }^{14}$ Three patients with angiofibromas and shagreen patches were observed after treatment cessation of between 6 and 48 months; shagreen patches, but not angiofibromas, worsened after treatment discontinuation. ${ }^{14}$

Oral everolimus has been evaluated in several studies of patients with SEGA, renal angiomyolipomas, LAM and epilepsy associated with TSC. ${ }^{15} 16{ }^{29-35}$ Oral everolimus is approved by the FDA and EMA for the treatment of certain TSC-associated

Table 2 Treatment options for tuberous sclerosis complex-associated skin, mucocutaneous and dental manifestations ${ }^{13}$

\begin{tabular}{|c|c|c|c|}
\hline Condition & Treatment options & & Additional considerations \\
\hline \multirow[t]{4}{*}{ Facial angiofibroma } & $\begin{array}{l}\text { Topical mTOR } \\
\text { inhibitors }\end{array}$ & $\begin{array}{l}\text { Rapid response in weeks after initiating therapy } \\
\text { May be more effective for small early lesions and for preventing } \\
\text { recurrence after surgery } \\
\text { Well tolerated with no systemic toxicity }\end{array}$ & - Continual therapy necessary \\
\hline & Vascular laser surgery & $\begin{array}{l}\text { Consider pulsed-dye laser for erythematous lesions } \\
\text { Effect may be enhanced when combined with } 5 \text {-aminolevulinic acid }\end{array}$ & Temporary improvement \\
\hline & Ablative laser surgery & Consider for fibrotic lesions & $\begin{array}{l}\text { Sedation or general anaesthesia may be } \\
\text { necessary }\end{array}$ \\
\hline & Surgical excision & $\begin{array}{l}\text { - Consider for symptomatic large lesions } \\
\text { - Also consider for single or fewer fibrotic lesions }\end{array}$ & Sedation may be necessary \\
\hline Fibrous cephalic plaque & Surgical intervention & - Consider if rapid progression and/or disfiguring & $\begin{array}{l}\text { Sedation may be necessary } \\
\text { Surgical risks }\end{array}$ \\
\hline Skin tags & Snip excision & - Treatment usually not necessary, but consider if symptomatic & - Minimal surgical risk \\
\hline Hypomelanotic macules & $\begin{array}{l}\text { Topical mTOR } \\
\text { inhibitors }\end{array}$ & $\begin{array}{l}\text { Treatment usually not necessary, but consider for cosmetic sensitive } \\
\text { area on the face }\end{array}$ & $\begin{array}{l}\text { Long-term treatment may be necessary } \\
\text { High cost }\end{array}$ \\
\hline $\begin{array}{l}\text { Periungual/subungual } \\
\text { fibroma }\end{array}$ & $\begin{array}{l}\text { Ablative laser } \\
\text { Surgical excision }\end{array}$ & - Consider if lesions symptomatic or $>3 \mathrm{~mm}$ & Repeated treatment may be necessary \\
\hline Intraoral fibroma & $\begin{array}{l}\text { Good oral hygiene } \\
\text { Other options }\end{array}$ & $\begin{array}{l}\text { To minimise irritation } \\
\text { If obstructive, consider electrocautery, ablative laser or surgical } \\
\text { excision }\end{array}$ & $\begin{array}{l}\text { None } \\
\text { Sedation may be necessary }\end{array}$ \\
\hline Dental pits & $\begin{array}{l}\text { Good dental hygiene } \\
\text { Restoration }\end{array}$ & - Consider if at risk for dental caries & $\begin{array}{l}\text { None } \\
\text { Sedation may be necessary }\end{array}$ \\
\hline Jaw cysts & $\begin{array}{l}\text { Curettage, surgical } \\
\text { excision }\end{array}$ & - Consider if at risk for bony destruction & - Sedation may be necessary \\
\hline
\end{tabular}

Reproduced with permission from JAMA Dermatology 2014;150:1095-1101. Copyright 2014 American Medical Association. All rights reserved.

mTOR, mammalian target of rapamycin. 
SEGAs and renal angiomyolipomas. ${ }^{21}$ The effect of oral everolimus on skin lesions was evaluated prospectively as a secondary endpoint in two pivotal phase III studies, EXIST-1 and EXIST-2. ${ }^{15} 16$ The skin lesion response rate, based on the Physician's Global Assessment, was significantly higher for everolimus than for placebo in both studies. ${ }^{15} 16$ The clinical experience gained from these trials indicates that oral everolimus is effective in improving cutaneous TSC lesions. ${ }^{16}$ Although thought to be effective in treating cutaneous TSC manifestations, oral mTOR inhibitors are currently reserved for patients whose internal disease warrants systemic treatment.

\section{Non-systemic therapies (topical mTOR inhibitors)}

Rapamycin (sirolimus) is a lipophilic compound ${ }^{22}$ that has been examined in numerous topical formulations of different concentrations and bases for the treatment of certain dermatological diseases. Studies demonstrate that topical mTOR inhibitors are effective for the management of several TSC skin lesions; ${ }^{36-40}$ however, no formulation is currently commercially available.

Consensus guidelines indicate that topical mTOR inhibitors are an effective treatment option for angiofibromas. They provide rapid response by flattening lesions and decreasing erythema. In some patients, particularly children with smaller lesions, almost complete resolution has been achieved. ${ }^{13} 41$ There are few known side effects of topical mTOR inhibitors, and they appear to be dependent on the formulation; 3640 blood drug levels are reportedly undetectable. ${ }^{13}{ }^{42}$ Topical mTOR inhibitor solutions can cause skin irritation, ${ }^{13} 36$ which can be managed through dose reduction, addition of topical steroids $^{36}$ or change of formulation to an ointment or gel. It seems that continual use is necessary for sustained benefit, but data on long-term safety and appropriate dosing are still lacking.

A recent review analysed 16 reports of topical rapamycin for the management of angiofibromas, which included ointments, gels, solutions and creams, with rapamycin concentrations ranging from $0.003 \%$ to $1 \%$. $^{36}$ Treatment was associated with moderate to complete clearance of lesions in $94 \%$ of the cases identified. Furthermore, no recurrences were seen with continued use; the longest treatment duration was 30 months. In most cases, side effects were absent, with the exception of cutaneous irritation, which was mainly restricted to patients using topical rapamycin formulated as a solution. Laser therapy can be used adjunctively with topical rapamycin as an effective treatment option for facial angiofibromas. ${ }^{43}$ In addition to facial angiofibromas, topical rapamycin has been reported to be effective in the treatment of other cutaneous TSC findings. For hypopigmented macules, treatment is generally not necessary. However, for cosmetically sensitive areas such as the face, topical mTOR inhibitors have demonstrated improvement in some cases. ${ }^{37} 38$ Additionally, a single report shows improvement in subungual fibromas with topical rapamycin. ${ }^{39}$

Evidence on topical everolimus is limited to a case study of a 10 -year-old girl treated for facial angiofibromas. ${ }^{40}$ A petrolatum ointment containing $0.4 \%$ everolimus was applied once daily, and positive results were seen after 3-6 months of treatment. However, angiofibromas worsened when the strength of topical everolimus was lowered to $0.1 \%$, even when applied twice daily. The only notable adverse effect of this topical formulation was photosensitivity at the application site, which resolved in 2 days; systemic everolimus levels were not detected.

\section{Non-pharmacological therapies}

Before the advent of mTOR inhibitors, surgery and other nonpharmacological therapies were the mainstay of treatment for
TSC-associated skin lesions and, in some cases, are still the treatment of choice. Erythematous lesions may respond well to pulsed-dye laser treatment, which may be enhanced by the addition of 5-aminolevulinic acid. ${ }^{13} 4546$ Additionally, use of ablative lasers can be helpful for fibrotic lesions, and surgical excision can be appropriate for large symptomatic lesions. ${ }^{13}$ A range of surgical approaches has been used to treat facial angiofibromas, including dermabrasion, cryosurgery, curettage, shave excision and chemical peels. ${ }^{9} 134748$

In patients with symptomatic or large periungual fibromas, the use of ablative lasers or surgical excision are reasonable options. $^{13}{ }^{49}$ It is important to counsel patients that even with surgical removal, recurrence is possible. ${ }^{50}$ In patients who are not candidates for surgery, the use of carbon dioxide laser or other ablative laser treatments of periungual fibromas might be effective. ${ }^{51}$ Shave excision of the tumour followed by phenol application is another treatment option. ${ }^{49} 52$ In patients with shagreen patches, the levelling of elevated lesions with a Reese dermatome might be a viable cosmetic treatment option. ${ }^{53}$ For fibrous cephalic plaques that are disfiguring or rapidly progressing, surgical intervention is occasionally necessary. ${ }^{13}$

\section{GENERAL PAEDIATRICIAN ROLE IN MANAGEMENT}

Paediatricians should be knowledgeable about the diagnostic criteria and cutaneous signs of TSC in order to facilitate timely diagnosis. Also, because TSC-related manifestations can change during the course of a patient's illness, ongoing surveillance is important to account for the potential emergence of new or progressing sequelae. ${ }^{7}$ In addition to new or growing tumours and cutaneous lesions, many patients with TSC exhibit tuberous sclerosis-associated neuropsychiatric disorder (TAND), which include behavioural symptoms and psychiatric, intellectual, academic, neurological and psychosocial manifestations. ${ }^{54} 55$ These can be assessed using a TAND checklist, which is administered by the clinician to the parent and/or child with TSC. ${ }^{54}$ Paediatricians should be aware of these symptoms and educate patients and their parents on available services and treatments. Given that TSC is a multisystem disease, the comprehensive assessment, surveillance and treatment of these patients will necessitate orchestration of multidisciplinary approaches involving numerous subspecialties, including dentistry, neurology, nephrology, dermatology, cardiology, ophthalmology and pulmonology (primarily in adult females), to monitor and treat TSC-associated manifestations. ${ }^{7}$ Consensus guidelines recommend a thorough baseline assessment of patients with newly diagnosed or suspected TSC, followed by ongoing monitoring of those with a definite or probable diagnosis (table 3$)^{7}$

Paediatricians also play an important role in educating families about the genetic basis of TSC, ordering genetic tests, reviewing considerations for parental evaluations for TSC, instructing parents about potential implications for other family members and consideration of referral for genetic counselling.

\section{CONCLUSION}

Skin lesions are frequently reported in individuals with TSC and are potentially disfiguring, painful or emotionally distressing. The advent of targeted therapy with mTOR inhibitors has proved promising for the treatment of TSC-associated skin lesions. Although topical formulations of mTOR inhibitors seem to be better tolerated than systemic therapies, adequately powered and controlled prospective studies are necessary to confirm the efficacy and safety of topical sirolimus or everolimus in various subtypes of TSC-associated skin manifestations. Oral 
Table 3 Consensus guideline recommendations for baseline assessment and ongoing monitoring of tuberous sclerosis complex (TSC) ${ }^{7}$

\begin{tabular}{|c|c|c|}
\hline \multirow{2}{*}{$\begin{array}{l}\text { Organ system or } \\
\text { specialty area }\end{array}$} & \multicolumn{2}{|l|}{ Recommendations } \\
\hline & Baseline workup for newly diagnosed or suspected TSC & Ongoing monitoring of definite or possible TSC \\
\hline Genetics & $\begin{array}{l}\text { Three-generation family history to determine TSC risk in } \\
\text { additional family members } \\
\text { - Offer genetic testing/family counselling }\end{array}$ & $\begin{array}{l}\text { Genetic testing/family counselling in individuals of reproductive age } \\
\text { or newly considering having children }\end{array}$ \\
\hline Brain & $\begin{array}{l}\text { MRI to identify presence of tubers, subependymal nodules, } \\
\text { migrational defects and SEGA } \\
\text { Screen for TAND } \\
\text { Educate parents on infantile spasms during infancy } \\
\text { Perform baseline EEG; if abnormal, follow-up with 24-hour video } \\
\text { EEG to assess for subclinical seizure activity }\end{array}$ & $\begin{array}{l}\text { MRI every 1-3 years if asymptomatic and aged }<25 \text { years; more frequent } \\
\text { MRIs in asymptomatic patients with large or growing SEGAs } \\
\text { Screen for TAND annually; comprehensive formal TAND evaluation at key } \\
\text { developmental time points (particularly at } 0-3,3-6,6-9,12-16 \text { and } \\
18-25 \text { years) } \\
\text { - Routine EEG in patients with known or suspected seizure activity }\end{array}$ \\
\hline Kidney & $\begin{array}{l}\text { MRI of the abdomen to identify angiomyolipoma and renal cysts } \\
\text { Measure BP to screen for hypertension } \\
\text { Measure GFR to assess renal function }\end{array}$ & $\begin{array}{l}\text { MRI of the abdomen every } 1-3 \text { years throughout lifetime of the patient } \\
\text { Measure BP and GFR annually }\end{array}$ \\
\hline Lung & $\begin{array}{l}\text { Baseline pulmonary function testing, 6-minute walk test and } \\
\text { HRCT if at risk for LAM (typically women } \geq 18 \text { years) } \\
\text { - Counsel on smoking risks and oestrogen use }\end{array}$ & $\begin{array}{l}\text { Clinical screening for LAM (ie, exertional dyspnoea) symptoms at each } \\
\text { clinic visit } \\
\text { Ongoing counselling on smoking risks and oestrogen use for patients at } \\
\text { risk for LAM } \\
\text { HRCT every } 5-10 \text { years in absence of lung cysts at baseline scan or every } \\
2-3 \text { years if lung cysts present } \\
\text { - Pulmonary function testing and 6-minute walk test annually if lung cysts } \\
\text { present at baseline }\end{array}$ \\
\hline Heart & $\begin{array}{l}\text { ECG in all ages to identify underlying conduction defects } \\
\text { Echocardiography in patients } \leq 3 \text { years } \\
\text { If rhabdomyomas are identified via prenatal ultrasound, consider } \\
\text { fetal echocardiography after delivery to assess risk for heart } \\
\text { failure }\end{array}$ & $\begin{array}{l}\text { ECG every } 3-5 \text { years in all ages if asymptomatic } \\
\text { Echocardiography every } 1-3 \text { years in asymptomatic paediatric patients until } \\
\text { cardiac rhabdomyomas regress } \\
\text { Might necessitate more frequent or advanced diagnostics for symptomatic } \\
\text { patients }\end{array}$ \\
\hline Skin & - Detailed dermatological examination & - Detailed dermatological examination annually \\
\hline Teeth & - Detailed dental examination & $\begin{array}{l}\text { Detailed dental examination every } 6 \text { months } \\
\text { Panoramic radiography by } 7 \text { years of age }\end{array}$ \\
\hline Eye & $\begin{array}{l}\text { - Complete ophthalmological evaluation (including dilated } \\
\text { funduscopy) to identify retinal lesions and visual field defects }\end{array}$ & $\begin{array}{l}\text { - Ophthalmological evaluations annually if ophthalmological lesions or vision } \\
\text { symptoms present at baseline evaluation }\end{array}$ \\
\hline
\end{tabular}

Reproduced from Krueger DA, et al. Tuberous Sclerosis Complex Surveillance and Management: Recommendations of the 2012 International Tuberous Sclerosis Complex Consensus Conference. Pediatric Neurology 2013;49:255-65. Copyright 2013, with permission from Elsevier.

BP, blood pressure; GFR, glomerular filtration rate; HRCT, high-resolution chest CT; LAM, lymphangioleiomyomatosis; SEGA, subependymal giant cell astrocytoma; TAND, tuberous sclerosis complex-associated neuropsychiatric disorder.

mTOR inhibitors, approved to treat internal manifestations of TSC such as SEGAs and renal angiomyolipomas, have also been effective in cutaneous disease.

TSC is a lifelong disease in which tumours may develop in multiple organ systems over a patient's lifetime; therefore, early diagnosis is paramount. Many types of TSC-associated skin lesions can develop at birth or during early childhood, highlighting the role of the paediatrician in the diagnosis of the disease. Therefore, awareness in the paediatric community of TSC-associated skin lesions is critical to ensure that patients receive an early diagnosis and systemic workup, timely initiation of treatment strategies and appropriate referrals for follow-up care.

Acknowledgements Editorial assistance was provided by Maxwell Chang and Traci Stuve of ApotheCom (Yardley, Pennsylvania, USA).

Funding Editorial assistance was funded by Novartis Pharmaceuticals Corporation.

Competing interests None.

Patient consent Parental/guardian consent obtained.

Provenance and peer review Not commissioned; externally peer reviewed.

Open Access This is an Open Access article distributed in accordance with the Creative Commons Attribution Non Commercial (CC BY-NC 4.0) license, which permits others to distribute, remix, adapt, build upon this work non-commercially, and license their derivative works on different terms, provided the original work is properly cited and the use is non-commercial. See: http://creativecommons.org/ licenses/by-nc/4.0/

\section{REFERENCES}

1 Crino PB, Nathanson KL, Henske EP. The tuberous sclerosis complex. N Engl J Med 2006;355:1345-56

2 Hyman $\mathrm{MH}$, Whittemore $\mathrm{VH}$. National Institutes of Health consensus conference: tuberous sclerosis complex. Arch Neurol 2000;57:662-5.

3 Osborne JP, Fryer A, Webb D. Epidemiology of tuberous sclerosis. Ann N Y Acad Sci 1991:615:125-7.

4 Huang J, Manning BD. The TSC1-TSC2 complex: a molecular switchboard controlling cell growth. Biochem J 2008;412:179-90.

5 Curatolo P, Bombardieri R, Jozwiak S. Tuberous sclerosis. Lancet 2008;372:657-68.

6 Northrup H, Krueger DA. Tuberous sclerosis complex diagnostic criteria update: recommendations of the 2012 International Tuberous Sclerosis Complex Consensus Conference. Pediatr Neurol 2013:49:243-54.

7 Krueger DA, Northrup H. Tuberous sclerosis complex surveillance and management: recommendations of the 2012 International Tuberous Sclerosis Complex Consensus Conference. Pediatr Neurol 2013;49:255-65.

8 Bolognia JL, Jorizzo JL, Schaffer JV. Dermatology. 3rd edn. Elsevier, 2012:1-2776.

9 Schwartz RA, Fernández G, Kotulska K, et al. Tuberous sclerosis complex: advances in diagnosis, genetics, and management. J Am Acad Dermatol 2007;57:189-202.

10 Jóźwiak S, Schwartz RA, Janniger CK, et al. Skin lesions in children with tuberous sclerosis complex: their prevalence, natural course, and diagnostic significance. Int J Dermatol 1998:37:911-7.

11 Huggins RH, Schwartz RA, Janniger C. Vitiligo. Acta Dermatovenerol Alp Pannonica Adriat 2005; 14:137-42, 144-5.

12 Webb DW, Clarke A, Fryer A, et al. The cutaneous features of tuberous sclerosis: a population study. Br J Dermatol 1996;135:1-5.

13 Teng JM, Cowen EW, Wataya-Kaneda M, et al. Dermatologic and dental aspects of the 2012 International Tuberous Sclerosis Complex Consensus Statements. JAMA Dermatol 2014;150:1095-101.

14 Nathan N, Wang JA, Li S, et al. Improvement of tuberous sclerosis complex (TSC) skin tumors during long-term treatment with oral sirolimus. J Am Acad Dermatol 2015;73:802-8 
15 Franz DN, Belousova E, Sparagana S, et al. Efficacy and safety of everolimus for subependymal giant cell astrocytomas associated with tuberous sclerosis complex (EXIST-1): a multicentre, randomised, placebo-controlled phase 3 trial. Lancet 2013:381:125-32.

16 Bissler JJ, Kingswood JC, Radzikowska E, et al. Everolimus for angiomyolipoma associated with tuberous sclerosis complex or sporadic lymphangioleiomyomatosis (EXIST-2): a multicentre, randomised, double-blind, placebo-controlled trial. Lancet 2013:381:817-24.

17 Ventura-Aguiar P, Campistol JM, Diekmann F. Safety of mTOR inhibitors in adult solid organ transplantation. Expert Opin Drug Saf 2016;15:303-19.

18 Koch M, Wiech T, Marget M, et al. De novo mTOR inhibitor-based immunosuppression in ABO-incompatible kidney transplantation. Clin Transplant 2015:29:1021-8

19 Nashan B, Citterio F. Wound healing complications and the use of mammalian target of rapamycin inhibitors in kidney transplantation: a critical review of the literature. Transplantation 2012;94:547-61.

20 Yang $H$, Rudge DG, Koos JD, et al. mTOR kinase structure, mechanism and regulation. Nature 2013;497:217-23.

21 AFINITOR (everolimus) tablets for oral administration. East Hanover, NJ: Novartis Pharmaceuticals Corp, 2015.

22 Wyeth Pharmaceuticals Inc. RAPAMUNE-sirolimus tablet, sugar coated. Philadelphia PA: Wyeth Pharmaccuticals Inc, 2015

23 Davies DM, de Vries PJ, Johnson SR, et al. Sirolimus therapy for angiomyolipoma in tuberous sclerosis and sporadic lymphangioleiomyomatosis: a phase 2 trial. Clin Cancer Res 2011;17:4071-81.

24 Bissler JJ, McCormack FX, Young LR, et al. Sirolimus for angiomyolipoma in tuberous sclerosis complex or lymphangioleiomyomatosis. N Engl J Med 2008:358:140-51.

25 Dabora SL, Franz DN, Ashwal S, et al. Multicenter phase 2 trial of sirolimus for tuberous sclerosis: kidney angiomyolipomas and other tumors regress and VEGF-D levels decrease. PLoS One 2011;6:e23379.

26 Franz DN, Leonard J, Tudor C, et al. Rapamycin causes regression of astrocytomas in tuberous sclerosis complex. Ann Neurol 2006;59:490-8.

27 Cardamone M, Flanagan D, Mowat D, et al. Mammalian target of rapamycin inhibitors for intractable epilepsy and subependymal giant cell astrocytomas in tuberous sclerosis complex. J Pediatr 2014;17:631-8.

28 Cabrera-López C, Martí T, Catalá V, et al. Assessing the effectiveness of rapamycin on angiomyolipoma in tuberous sclerosis: a two years trial. Orphanet $J$ Rare Dis 2012;7:87.

29 Krueger DA, Care MM, Holland K, et al. Everolimus for subependymal giant-cell astrocytomas in tuberous sclerosis. N Engl J Med 2010;363:1801-11.

30 Franz DN, Belousova E, Sparagana S, et al. Everolimus for subependymal giant cell astrocytoma in patients with tuberous sclerosis complex: 2-year open-label extension of the randomised EXIST-1 study. Lancet Oncol 2014;15:1513-20.

31 Bissler JJ, Kingswood JC, Radzikowska E, et al. Everolimus for renal angiomyolipoma in patients with tuberous sclerosis complex or sporadic lymphangioleiomyomatosis: extension of a randomized controlled trial. Nephrol Dial Transplant 2016;31:111-19.

32 Krueger DA, Care MM, Agricola K, et al. Everolimus long-term safety and efficacy in subependymal giant cell astrocytoma. Neurology 2013:80:574-80.

33 Krueger DA, Wilfong AA, Holland-Bouley $\mathrm{K}$, et al. Everolimus treatment of refractory epilepsy in tuberous sclerosis complex. Ann Neurol 2013;74:679-87.

34 Goldberg HJ, Harari S, Cottin V, et al. Everolimus for the treatment of lymphangioleiomyomatosis: a phase II study. Eur Respir J 2015;46:783-94.
35 Franz DN, Agricola K, Mays M, et al. Everolimus for subependymal giant cell astrocytoma: 5-year final analysis. Ann Neurol 2015;78:929-38.

36 Balestri R, Neri I, Patrizi A, et al. Analysis of current data on the use of topical rapamycin in the treatment of facial angiofibromas in tuberous sclerosis complex. J Eur Acad Dermatol Venereol 2015;29:14-20.

37 Wataya-Kaneda M, Tanaka M, Nakamura A, et al. A novel application of topical rapamycin formulation, an inhibitor of mTOR, for patients with hypomelanotic macules in tuberous sclerosis complex. Arch Dermatol 2012;148:138-9.

38 Knöpfel N, Maítin-Santiago A, Bauza A, et al. Topical $0.2 \%$ rapamycin to treat facial angiofibromas and hypomelanotic macules in tuberous sclerosis. Actas Dermosifiliogr 2014;105:802-3.

39 Muzic JG, Kindle SA, Tollefson MM. Successful treatment of subungual fibromas of tuberous sclerosis with topical rapamycin. JAMA Dermatol 2014;150:1024-5.

40 Dill PE, De Bernardas G, Weber P, et al. Topical everolimus for facial angiofibromas in the tuberous sclerosis complex. A first case report. Pediatr Neurol 2014;51:109-13.

41 Tu J, Foster RS, Bint LJ, et al. Topical rapamycin for angiofibromas in paediatric patients with tuberous sclerosis: follow up of a pilot study and promising future directions. Australas J Dermatol 2014;55:63-9.

42 Koenig MK, Hebert AA, Roberson J, et al. Topical rapamycin therapy to alleviate the cutaneous manifestations of tuberous sclerosis complex: a double-blind, randomized, controlled trial to evaluate the safety and efficacy of topically applied rapamycin. Drugs $R$ D 2012;12:121-6.

43 Park J, Yun SK, Cho YS, et al. Treatment of angiofibromas in tuberous sclerosis complex: the effect of topical rapamycin and concomitant laser therapy. Dermatology 2014;228:37-41.

44 Bae-Harboe YS, Geronemus RG. Targeted topical and combination laser surgery for the treatment of angiofibromas. Lasers Surg Med 2013:45:555-7.

45 Boixeda P, Sánchez-Miralles E, Azaña JM, et al. CO2, argon, and pulsed dye laser treatment of angiofibromas. J Dermatol Surg Oncol 1994;20:808-12.

46 Weinberger $\mathrm{CH}$, Endrizzi B, Hook KP, et al. Treatment of angiofibromas of tuberous sclerosis with 5 -aminolevulinic acid blue light photodynamic therapy followed by immediate pulsed dye laser. Dermatol Surg 2009;35:1849-51.

47 Fischer $\mathrm{K}$, Blain B, Zhang F, et al. Treatment of facial angiofibromas of tuberous sclerosis by shave excision and dermabrasion in a dark-skinned patient. Ann Plast Surg 2001;46:332-5.

48 Sener S, Sasmaz S. Segmental tuberous sclerosis in a patient presenting as unilateral facial angiofibromas, periungual fibromas and Shagreen patch. Eur Rev Med Pharmacol Sci 2011:15:980-2.

49 Liebman JJ, Nigro LC, Matthews MS. Koenen tumors in tuberous sclerosis: a review and clinical considerations for treatment. Ann Plast Surg 2014;73:721-2.

50 Hake S. Cutaneous manifestations of tuberous sclerosis. Ochsner J 2010;10:200-4

51 Berlin AL, Billick RC. Use of $\mathrm{CO} 2$ laser in the treatment of periungual fibromas associated with tuberous sclerosis. Dermatol Surg 2002;28:434-6.

52 Mazaira M, del Pozo Losada J, Fernández-Jorge B, et al. Shave and phenolization of periungual fibromas, Koenen's tumors, in a patient with tuberous sclerosis. Dermatol Surg 2008;34:111-13.

53 Wendt JR, Watson LR. Cosmetic treatment of shagreen patches in selected patients with tuberous sclerosis. Plast Reconstr Surg 1991;87:780-2.

54 de Vries PJ, Whittemore VH, Leclezio L, et al. Tuberous sclerosis associated neuropsychiatric disorders (TAND) and the TAND Checklist. Pediatr Neurol 2015;52:25-35

55 Curatolo P, Moavero R, de Vries PJ. Neurological and neuropsychiatric aspects of tuberous sclerosis complex. Lancet Neurol 2015;14:733-45. 